\title{
Pears: An Alternative Feed
}

\author{
JOHN M. HARPER, Livestock and Natural Resources Advisor, \\ University of California Cooperative Extension, \\ Mendocino and Lake Counties
}

In 2006 the pear industry in Lake and Mendocino Counties experienced up to 30 percent crop losses due to lack of qualified pickers to harvest the crop. These losses may have been a one-time problem, but cull pears happen every year and represent an annual problem to the pear industry. While little can be done to salvage the direct loss of high-grade fruit, an opportunity exists for ruminant (cattle, sheep, or goats) livestock producers to recoup some of this loss by turning it into a quality feed source.

Fruits, unlike other crop residues that are universally low-quality roughages, are an excellent source of energy for ruminant animals. Fresh pears used in a cattle ration, for example, have TDN (total digestible nutrients) values of 87 percent, which is the same as 46-48 bushel weight barley. Rations high in fresh pear content must be supplemented with protein, minerals, and fiber content. In feeding trials with cattle in California, it was noted that dry cows and 2-year-old heifers consumed an average of 20 pounds of pears daily without noticeable bad effects. In comparing cattle responses to feeding on peaches and pears, the animals seemed to find spoiled pears more objectionable (Bath et al. 1980; NRC 1983).

Since pears are high-moisture content feeds (the average pear dry matter is 17 percent), care must be taken to insure that animals only consume half or less of their ration's dry matter from the high-moisture feed. Ruminants will eat about 2.5 to 3.5 percent of their body weight per day when the feed is in a dry form such as hay and grains (90 percent dry matter), but they cannot eat this much if it is high in moisture content. The reason is one of rumen capacity; the rumen (stomach) will not hold enough highmoisture feed to fulfill the animal's nutrient needs. Many high-moisture feeds are often quite palatable, and if given free choice, the animals will fill up on such feeds to satisfy their appetites, resulting in weight loss and reduced milk production (in lactating animals). The maximum dry matter intake of an all-high-moisture ration is about 2 to 2.5 percent of body weight.

Cull fruits, when fed in large amounts, can be very laxative, so it is important to monitor their intake. Feeding some dry forage prior to access to the fruit is a good management idea. Cattle should be gradually acclimated to the pears by feeding 2 or 3 pounds as fed per day and increasing the amount 2 or 3 pounds as fed per day per head until they are getting the desired amounts. Smaller ruminants like sheep or goats should be started on about half the amount for cattle and increased proportionately. Usually fruit harvested for human consumption has been handled safely with respect to residual pesticides and would be safe to feed to livestock. If the livestock producer is unsure, have the fruit tested for pesticide residue prior to feeding.

One of the biggest problems with feeding fresh pears is their highly perishable nature. Two options to address this problem are possible: drying the pears or ensiling them. In the feeding trial mentioned above, it was noted that a somewhat larger quantity of dried pears than of dried peaches could be fed. In addition, dried pears fed up to 4.5 pounds per day over a 10-day period resulted in no noticeable loss of appetite and no laxative effect. However, drying pears is expensive in terms of energy expenditure. Making pear silage is probably the better method for preserving this feed resource. When pears that contain about $80 \%$ moisture are ensiled for cattle, 20 to 25 pounds of dry hay, straw, or chaff is run through the silage cutter with each 100 pounds of pears (Boyles 2000). The most economical method of ensiling is with large, airtight plastic bags commercially available for this purpose.

Timing is critical in salvaging pears for livestock feed. If the weather turns hot, the fruit will spoil 
before it can be fed or preserved through ensiling. Spoiled fruit should not be fed.

So how would one calculate the value of fresh pears or pear silage? In buying or selling feeds, sellers or purchasers should check price against values received or sold. An easy method is to calculate the cost per unit of nutrients. Since pears would be considered an energy feed, like barley, one can compare the cost per pound of total digestible nutrients (TDN) to arrive at a comparable price for the pear feed. Since fresh pears and barley are similar in TDN values (87 percent), checking with the local feed store or mill on the price for barley will give the seller and buyer a starting price for negotiation. Of course, many other factors affect the actual feeding value of each feed. The livestock producer will also want to consider such things as palatability, grade of feed, preparation of feed (such as ensiling), ingredients with which each feed is combined, and quantities of each feed fed (Ensminger, 1978).

Savvy livestock producers with the land space and skill may be able to look at cull pears or other unusual feedstuffs as a method for reducing their feed bills or extending their feed supplies. Savvy pear producers may want to think about ensiling pears and producing secondary income by selling pear silage to livestock producers.

\section{REFERENCES}

Bath, D. L., J. R. Dunbar, J. M. King, S. L. Berry, R. O. Leonard, and S. E. Olbrich. 1980. By-products and unusual feedstuffs in livestock rations. WREP No. 39, October.

Boyles, S. 2000. Feeding potato processing wastes and culls to cattle. Ohio State University Extension Publications Web site: http://beef.osu.edu/ library/potato.html.

Ensminger, M. E. 1978. Stockman's handbook. 5th ed. Danville, IL: Interstate Press.

NRC (National Research Council). 1983. Underutilized resources as animal feedstuffs. Washington, D.C.: National Academy Press.

\section{FOR FURTHER INFORMATION}

To order or obtain printed ANR publications and other products, visit the ANR Communication Services online catalog at http://anrcatalog.ucdavis.edu. You can also place orders by mail, phone, or FAX, or request a printed catalog of our products from:

University of California

Agriculture and Natural Resources

Communication Services

6701 San Pablo Avenue, 2nd Floor

Oakland, California 94608-1239

Telephone: (800) 994-8849 or (510) 642-2431

FAX: (510) 643-5470

E-mail inquiries: danrcs@ucdavis.edu

An electronic version of this publication is available on the ANR Communication Services Web site at http://anrcatalog.ucdavis.edu.

Publication 7266

ISBN-13: 978-1-60107-429-4

(C) 2007 by the Regents of the University of California, Division of Agriculture and Natural Resources. All rights reserved.

To simplify information, trade names of products have been used. No endorsement of named or illustrated products is intended, nor is criticism implied of similar products that are not mentioned or illustrated.

The University of California prohibits discrimination or harassment of any person on the basis of race, color, national origin, religion, sex, gender identity, pregnancy (including childbirth, and medical conditions related to pregnancy or childbirth), physical or mental disability, medical condition (cancer-related or genetic characteristics), ancestry, marital status, age, sexual orientation, citizenship, or status as a covered veteran (covered veterans are special disabled veterans, recently separated veterans, Vietnam era veterans, or any other veterans who served on active duty during a war or in a campaign or expedition for which a campaign badge has been authorized) in any of its programs or activities. University policy is intended to be consistent with the provisions of applicable State and Federal laws.

Inquiries regarding the University's nondiscrimination policies may be directed to the Affirmative Action/Staff Personnel Services Director, University of California, Agriculture and Natural Resources, 1111 Franklin Street, 6th Floor, Oakland, CA 94607-5201, (510) 987-0096. For a free catalog of other publications, call (800) 994-8849. For help downloading this publication, call (530) 297-4445.

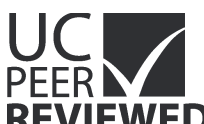

REVIEWED
This publication has been anonymously peer reviewed for technical accuracy by University of California scientists and other qualified professionals. This review process was managed by the ANR Associate Editor for Animal, Avian, and Aquaculture.

pr-01/07-LR/CM 